\title{
The Effect of Google SketchUp and Need for Achievement on the Students' Learning Achievement of Building Interior Design
}

\author{
https://doi.org/10.3991/ijet.v15i15.12471 \\ Nathanael Sitanggang $(\bowtie)$, Putri Lynna Adelinna Luthan \\ Universitas Negeri Medan, Medan, Indonesia \\ nathanaelsitanggang@unimed.ac.id \\ Felix Andika Dwiyanto \\ Universitas Negeri Malang, Malang, Indonesia
}

\begin{abstract}
This study aims to find out the effect of the Google SketchUp application and the need for achievement on students' learning achievements of building interior design. Quasi-experimental research was conducted at the Vocational High School (VHS) with a 2 × 2 factorial design. The Google SketchUp application was used in the experimental group, while the PowerPoint Slides were used in the control group. The sample consisted of 56 VHS students, study program of modeling design and building information. The instruments used are need for achievement tests and learning achievement tests with reliability coefficients of 0.916 and 0.671 . To test the hypothesis using multiple variance analysis techniques and the Tukey test. The results show that the Google SketchUp application is more effective than the PowerPoint in the learning of building interior design. Students who classified with a high need for achievement earn higher learning achievement compared to the lower one. There is an interaction between the Google SketchUp application and the students' need for achievement. For students who have a high need for motivation, using the Google SketchUp application is more effective than using PowerPoint Slides. On the other side, the students who have a low need for motivation, the use of the Google SketchUp application does not differ significantly compared to the use of PowerPoint Slides. This finding is very useful for vocational teachers as an effort to improve the learning process of building interior design. However, it is also possible that these findings can apply more broadly to student learning in other skills competencies in VHS. These findings contribute to the management of vocational education as an effort to implement VHS revitalization. Furthermore, it also can be used as a consideration by the Head of VHS and decisionmakers in the Ministry of Education and Culture.
\end{abstract}

Keywords-Google SketchUp, Need for Achievement, Learning Achievement, Building Interior Design. 


\section{Introduction}

Technological developments in the industrial revolution 4.0 allow automation in all fields to achieve effective and efficient productivity. The industrial revolution 4.0 is a combination of three main megatrends, namely physical, digital, and biological [1]. Physical megatrends are characterized by four main aspects, namely: autonomous vehicles, 3D printing, advanced robotics, and new materials. Digital megatrends are characterized by the use of the internet, commonly called the internet of all things (IoT). Meanwhile, biological megatrends are characterized by the development of synthetic biology. In addition, technological development raises the needs and challenges of the labor market. The needs of human resources require professional workers who are able to win the competition in labor competition [2]-[4]. In Indonesia, secondary education that prepares its graduates to become skilled workers is the Vocational High School (VHS). To improve the quality and competitiveness of vocational school graduates, a Presidential Instruction Number 9 of 2016 concerning the revitalization of VHS. According to the Presidential Instruction, the Ministry of Education and Culture has revised and adjusted the VHS curriculum to fit the competency needs of the business and industrial world called as Link and Match. The "Link" and "match" indicate that graduates have a competitive attitude, consisting of work ethics, motivation achievement, expertise, competitiveness, money beliefs, and attitudes to saving [5]. Completion and alignment of the VHS curriculum with business and industrial world are carried out by aligning the vocational education skills spectrum.

In this study, State Vocational School 1 Stabat, is one of the four referral VHS in North Sumatra Province included in 120 referral VHS in Indonesia and applying the skills spectrum in 2018. This school has 11 Departments that the number of students tends to increase each year. In the academic year 2017/2018 there were 1692 students; 2018/2019 1801 students; and 2019/2020 1921 students. In the study program of Construction and Property, it only opens the design modeling and building Information Department. It is because this Department attracts the attention of the citizen in the Stabat and surrounding areas. This is proved by the number of interested applicants for new students approximately 300 people each year, while the capacity is limited to 72 students. One of the productive subjects in this Department is Software Application and Building Interior Design. This subject consist of two vocational competencies which are software applications and building interior design. The learning achievements observed in this study are the learning achievements of building interior design. Based on the data of the last three years, students' learning achievement in the subject has not been satisfactory. It is because almost $20 \%$ of students are not successful. As an illustration, students who are not successful in 2016 are $13.89 \%$, in 2017 and 2018 respectively are $22.22 \%$. During this time, the application used by teachers in building interior design subject is PowerPoint slides. The PowerPoint slide app only shows 3D animated pictures. This 3D effect is commonly called a pop-out. There are three steps to creating 3D effects in PowerPoint, namely: (1) finding images suitable for presentations, (2) eliminate unnecessary background, and (3) Pop-Outs. PopOut is composing the selected image so that it looks like three dimensions. Figure 1 shows the sample of PowerPoint slides. 


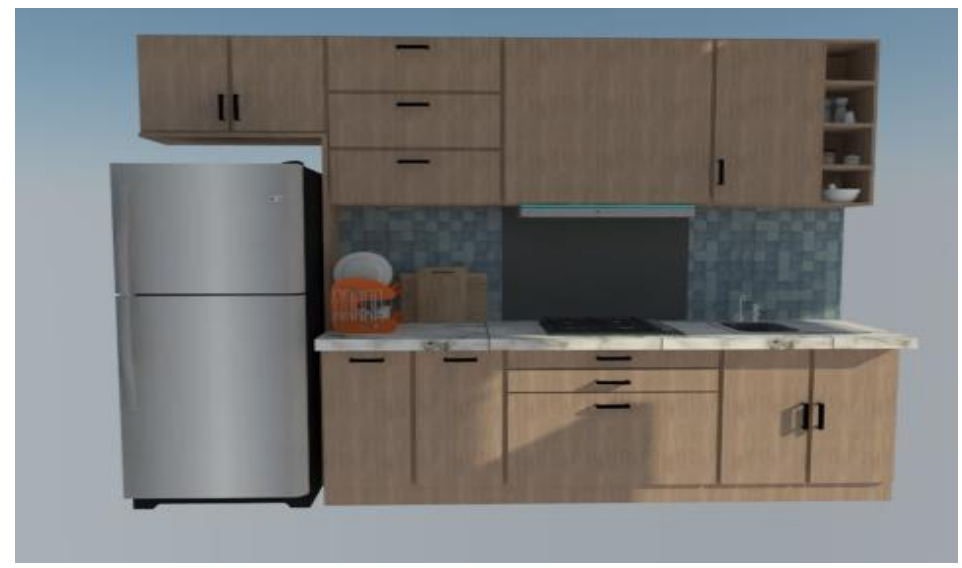

Fig. 1. Interior preview through PowerPoint slide

\section{Theoretical Framework}

\subsection{Google SketchUp application}

Currently, various technology used to assist the educational process. Especially in learning process technology-based learning has been developed and tested to assists and increase the effectiveness of learning. Those technology formed as media, device, game, application and so on [6]-[12]. In this case, it is necessary to increase student learning achievement in building interior design subject using technology. Efforts to improve learning achievement is to use the Google SketchUp application. Google SketchUp is software that can be used to model 3D objects. Google SketchUp is a 3D graphics program developed by Google that combines a set of tools that are simple, but very suitable for 3D graphic design on a computer screen. Google SketchUp consists of two versions which are open access and Pro version. The open access version can be used to design and create 3D objects, while the Pro version with LayOut is provided for professionals in the 3D graphics field. Figure 2 shows the preview of Google SketchUp application. The Google SketchUp application is very suitable for use in learning related to graphics and animation [13], [14]. The Google SketchUp application on building design is more efficient and effective if implemented into 3D design.

Based on the observation of the pre-test implementation using the Google SketchUp application, there are some students who have difficulty using the 3-button mouse (middle, right, and left). The ability to use the 3-button mouse is very important to use the Google SketchUp application. It is because the middle button (roll) functions for zoom, orbit, pan, re-center, and view. The right button functions for menus and contexts, while the left button functions for selection. The use of a 3-button mouse on the Google SketchUp application is not the same as using a 3-button mouse on other applications, such as PowerPoint slides, MS Excel, MS Word. 
Moreover, Learning can be defined as behavior changes that can produce an ability from the learning experience and interaction of students with their environment [15]. According to the statement, the students' ability of building interior design are: (1) able to present the basic principles of 3D images, (2) able to operate 3D drawing orders, (3) able to make 3D images using the material editor function, and (4) able to examine the results of $3 \mathrm{D}$ drawing rendering.

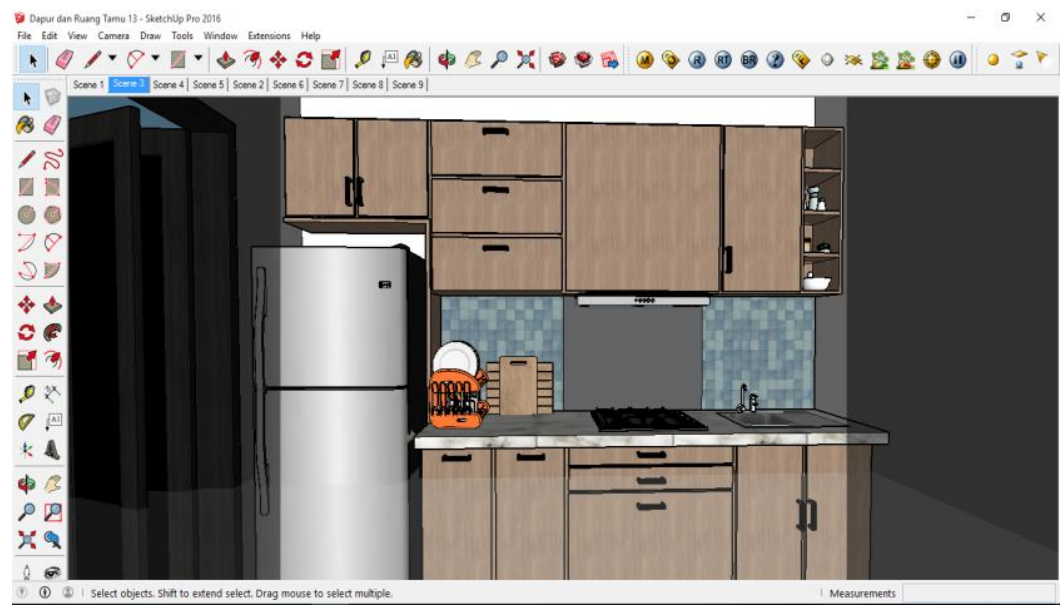

Fig. 2. Interior preview through Google SketchUp Application

From the description, it can be concluded that the use of 3D applications can clarify students' understanding of the building interior design. It also can be forming student learning experiences according to learning material starting from abstract material towards more tangible learning. The 3D application that fits the description above is using the Google SketchUp application.

\subsection{Need for Achievement (N-Ach)}

Furthermore, students' motivational factors must also be considered in learning the building interior design. In general, motivation can be interpreted as energy for someone to carry out their activities. The motivation affects student learning and behavior because it can direct behavior toward specific goals and influence cognitive processes [16]. There are three motivational functions in learning which are: a stimulus for action, driver of action, and as director of the act. Thus, motivation can make students more concentrate on learning, so that learning goals can be achieved properly. More specifically, the need for achievement is encouragement from within individuals to excel and strive hard to succeed [17]. The need for achievement is encouragement from within individuals to be able to achieve goals [18], [19]. From the description above it can be concluded that the need for achievement is an intrinsic motivation that comes from within the individual. Students who have a high need for achievement will study harder to achieve better performance it is because these students are not 
depending on external motivating factors. In addition the characteristics of individuals who have a high need for achievement, including do the best; do work successfully; completing tasks well; trying to do a better job than others [20].

\subsection{Learning achievement}

Moreover, it is known that the need for achievement factor can influence student achievement in building interior design subject. Learning achievement can be defined as learning outcomes that show how far students have been able to achieve the specified learning goals [21]. Therefore, it can be concluded that the influence of the use of the Google SketchUp application and the need for achievement factors is very important to observe through this study. Figure 3 shows a theoretical framework of this study. Based on the framework, it can be seen that need for achievement and Google SketchUp as a technology-based application influence the learning achievement of building interior design course. Based on the description, several problems arise, namely: (1) Is the use of the Google SketchUp application more effective than using PowerPoint slides? (2) Do students who are classified as a high need for achievement get higher learning achievement? (3) Is there an interaction between the use of the Google SketchUp application and the need for achievement motivation of students in building interior design learning?

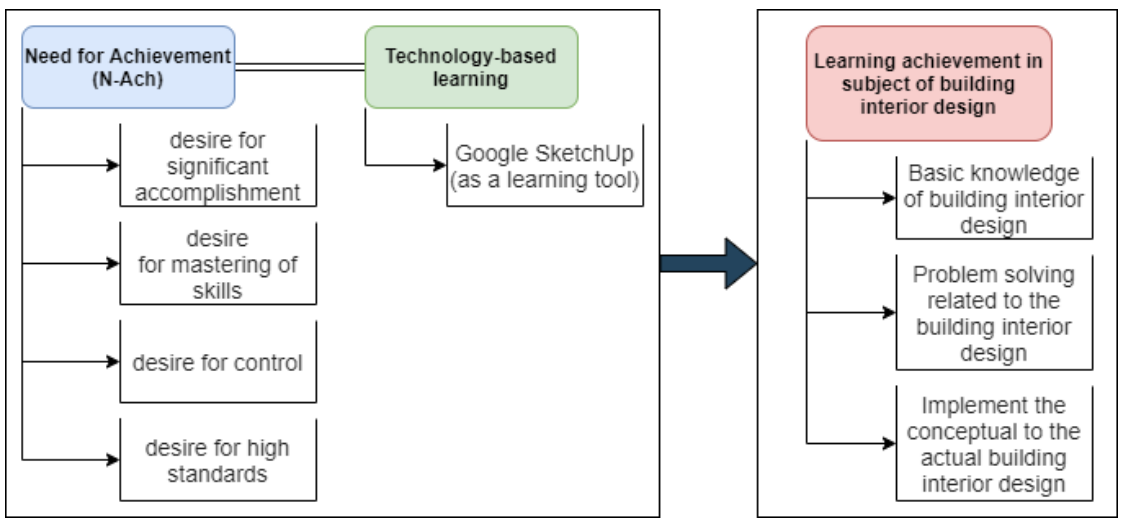

Fig. 3. Theoretical framework

Based on the introduction, the use of the Google SketchUp application will make it easier for students to learn about interior design since this application has an attractive interface that can make an attractive 3D modeling. Also, many open sources and plugins that support the performance of SketchUp, the 3D application is very light for computers and easy to get features through a 3D warehouse. While the use of PowerPoint slides only can display interior images with additional 3-dimensional animation. Therefore, it can be assumed that the use of the Google SketchUp application is more effective compared to the use of PowerPoint slides in learning the interior design. Furthermore, the effectiveness of using the Google SketchUp application in learning 
the interior design is influenced by a student's need for achievement. The motivational theory that explains the differences between someone who achieves the better of others [22]. Someone who has high need for achievement can face challenges based on their abilities. For students who have high need for achievement, the use of the Google SketchUp application makes them get the motivation to study hard to achieve better. Therefore, it can be shown that students who have high need for achievement will have higher achievement in learning. Whereas for students who have low need for achievement do not like to face more complex challenges in learning, so it is more fun to learn when using PowerPoint Slides. Therefore there is an interaction between the use of the Google SketchUp application and the level of student's motivation. For students who have high need for achievement, the use of the Google SketchUp application is more effective than using PowerPoint Slides. On the other hand, for students who have low need for achievement, the use of PowerPoint Slides is more effective than using the Google SketchUp application.

\section{Method}

\subsection{Research design}

This study using a quasi-experimental method with a $2 \times 2$ factorial design [23]. This method is very suitable to compare the effect of effectiveness between the use of the Google SketchUp, Slide PowerPoint applications and the need for achievement factors on the students' learning achievement of building interior design subject. The sample consisted of 56 students of State VHS 1 Stabat, North Sumatra, Indonesia. It divided into two groups which are 28 students in the experimental group who were treated using the Google SketchUp application, and 28 students in the control group were treated using Slide PowerPoint. Treatment for the experimental group and the control group was conducted four times with the same learning material which is the building interior design. The sample is determined by strata technique, which is high and low need for achievement. Table 1 shows the details of research design.

Table 1. $2 \mathrm{X} 2$ factorial research design

\begin{tabular}{|l|l|l|}
\hline \multicolumn{1}{|c|}{ Variable } & Google SketchUp Application (A1) & PowerPoint Slide Application (A2) \\
\hline High need for motivation $\left(\mathrm{B}_{1}\right)$ & $\mathrm{A}_{1} \mathrm{~B}_{1}$ & $\mathrm{~A}_{2} \mathrm{~B}_{1}$ \\
\hline Low need for motivation $\left(\mathrm{B}_{2}\right)$ & $\mathrm{A}_{1} \mathrm{~B}_{2}$ & $\mathrm{~A}_{2} \mathrm{~B}_{2}$ \\
\hline
\end{tabular}

From Table 1 it can be seen that A1B1 is the group of Google SketchUp applications for the student with a high need for motivation. A2B1 is the group of PowerPoint slides application for the student with a high need for motivation. A1B2 is the group of Google SketchUp application for the student with a low need for motivation. A2B1 is the group of PowerPoint slides application for the student with a low need for motivation. 


\subsection{External and Internal validity}

To ensure that the chosen factorial design is good enough for testing the research hypothesis, external validity and internal validity are controlled. External validity is controlled through population validity and ecological validity. While internal validity is controlled through the effect of history, the effect of saturation, the effect of initial tests, the effect of measurement instruments, the effect of differences in the selection of research subjects, the effect of losing experimental participants, and contamination between experimental classes. From the two experimental groups, students in group A learn by using the Google SketchUp application, and students in group B learn by using PowerPoint slides. In this study, two teachers were assigned, each teaching in group A and group B. Before the teacher carried out the task, an explanation was given about the application of the software that would be used in learning about interior design. Before students in group A and group B were treated, the similarity factors were first reviewed, which are: learning objective factors, student factors, situation factors, teacher factors, and facility factors. While the different factors are the use of 3D applications, the use of the Google SketchUp application in group A, and the use of PowerPoint slides in group B.

Classification of student's motivation is measured by a motivation test developed by the research team based on motivation theory, and student achievement is measured by a learning achievement test that is also developed by the research team based on the building interior syllabus. After testing the instrument, the validity of the achievement motivation test items was analyzed by Karl Pearson's product-moment correlation technique, and the reliability coefficient was calculated by the Alpha coefficient. After analyzing the trial data, it turns out that from 32 items of motivation test, 27 valid items were obtained, and the reliability coefficient was 0.916 . Next, the validity of the learning achievement test of the interior design was analyzed based on the difficulty index and distinguishing power index, and the reliability coefficient was calculated by the Kuder-Richardson formula (KR20). After analyzing the test data, it turns out that from the 20 items of interior design achievement test, 17 valid learning achievement tests were obtained, and the reliability coefficient was 0.671 . The reliability coefficient of both instruments is high and significant.

\subsection{Data analysis}

In accordance with the $2 \times 2$ factorial design research design, the analytical technique used for hypothesis testing is two-way variance analysis (ANAVA) and followed by the Tukey test. The use of ANAVA must meet the requirements for normality and homogeneity tests. For the normality test using the Kolmogorov-Simirnov, and for the homogeneity test using Levene's test.

The classification of the need for achievement is measured by the tests with a reliability coefficient of 0.916 . Then, the student learning achievement is measured by a building interior design learning achievement test with a reliability coefficient is 0.671. Research data were analyzed using Karl Pearson product moment correlation techniques [24], Alpha coefficients [25], Kuder-Richardson (KR20) test, Kolmogo- 
rov-Smirnov Test [26], Levene's test [27], Two-way Variance Analysis [28], and the Tukey test. The product moment is used to analyze the validity of need for achievement test items. The alpha coefficient is used to calculate the reliability coefficient of need for achievement test. Kuder-Richardson (KR20) is used to calculate the reliability coefficient of building interior design tests. Kolmogorov-Smirnov to test normality, Levene's test to test homogeneity. Two-way variance analysis and the Tukey test were used to test the hypothesis.

\section{$4 \quad$ Result and Discussion}

\subsection{Descriptive statistic result}

The tendency of the vocational students' need for achievement is analyzed based on ideal standard criteria and is classified into four, which are: high, sufficient, lacking, and low. After analysis, it found that $45.71 \%$ of SMK student motivation was high, $52.86 \%$ classified as sufficient, and $1.43 \%$ classified as lacking. Thus, it can be concluded that the vocational students' need for achievement classified as sufficient, although there are still $1.43 \%$, which are classified as lacking. While the results of descriptive statistical analysis of the learning achievement of vocational students in the interior designer are shown in Table 2.

Table 2. Descriptive statistic result

\begin{tabular}{|l|l|l|l|l|l|}
\hline & & \multicolumn{1}{|c|}{$\mathbf{A}_{\mathbf{1}} \mathbf{B}_{\mathbf{1}}$} & \multicolumn{1}{c|}{$\mathbf{A}_{\mathbf{2}} \mathbf{B}_{\mathbf{1}}$} & \multicolumn{1}{c|}{$\mathbf{A}_{\mathbf{1}} \mathbf{B}_{\mathbf{2}}$} & \multicolumn{1}{c|}{$\mathbf{A}_{\mathbf{2}} \mathbf{B}_{\mathbf{2}}$} \\
\hline $\mathrm{N}$ & Valid & 14 & 14 & 14 & 14 \\
& Missing & 0 & 0 & 0 & 0 \\
Mean & & 72,2857 & 7,7143 & 7,4286 & 8,3571 \\
Median & & 12,5000 & 7,0000 & 7,0000 & 8,0000 \\
Mode & 11,00 & 6,00 & $5,00 \mathrm{a}$ & 8,00 \\
Std.Deviation & 3,07417 & 2,30146 & 2,59331 & 2,92488 \\
Variance & 9,451 & 5,297 & 6,725 & 8,555 \\
Range & 11,00 & 7,00 & 9,00 & 10,00 \\
Minimum & & 5,00 & 5,00 & 4,00 & 4,00 \\
Maximum & & 12,00 & 13,00 & 14,00 \\
Sum & & 172,00 & 108,00 & 104,00 & 117,00 \\
\hline
\end{tabular}

Based on Table 2, it turns out that the highest students' learning achievement is in the group of students who use the Google SketchUp application with high need for achievement, with a range of scores between 0 to 17, the lowest score of 5 and the highest score of 16, the average price 12.28, and standard deviation 3.07. While the lowest SMK student learning achievement is in the group of students who use the Google SketchUp application whose motivation is low, with a range of scores between 0 to 17, the lowest score of 4 and the highest score of 13, an average price of 7.42, and a standard deviation of 2.59. Based on Table 2 also, it is shown that for SMK students who use PowerPoint slides, it turns out that students with low motivation (Mean $=8.35 ; \mathrm{SD}=2.92$ ) have higher learning achievement compared to students who have high motivation $($ Mean $=7.71 ; \mathrm{SD}=2.30)$. 
Overall, the learning achievement of vocational student groups using the Google SketchUp application (Mean $=9.85$; SD $=3.72$ ) is higher than the group of students who use PowerPoint slides (Mean $=8.03$; $\mathrm{SD}=2.60$ ) in the interior design. Therefore, Table 2 illustrates that the average score of learning achievement in interior design with the use of the Google SketchUp application is greater than the average score of learning achievement in interior design with the use of PowerPoint slides. But conversely, in the group using PowerPoint Slides, it turns out that the average score of learning achievement in the interior design of students whose motivation is low has a greater score than the average score for the student which has high need for achievement.

Based on the descriptive analysis result using the ideal standard as a criterion, the tendency of students' need for achievement is in the sufficient category. In details, $45.71 \%$ of students' need for achievement is high, $52.86 \%$ is classified as sufficient, and $1.43 \%$ is classified as insufficient.

Through the Google SketchUp Application, overall students' learning achievement measured with scores ranges 0 to 17 . It gained the lowest score is 4 , the highest score is 16 , the average is 9.85 , and the standard deviation is 3.72 . While the PowerPoint slides application, overall students' learning achievement measured with scores ranges 0 to 17 . It gained the lowest score is 4 , the highest score is 14 , the average is 8.03 , and the standard deviation is 2.60 .

The use of Google SketchUp on students' learning achievement with a high need for achievement is measured with scores ranges 0 to 17 . It gained the lowest score is 5 , the highest score is 16 , the average is 12.28 , and the standard deviation is 3.07. While the students' learning achievement with a low need for achievement, it gained the lowest score is 4 , the highest score is 13 , the average is 7.42 , and the standard deviation is 2.59

Next, the use of PowerPoint slides on students' learning achievement with a high need for achievement is measured with scores ranges 0 to 17 . It gained the lowest score is 5 , the highest score is 12 , the average is 7.71 , and the standard deviation is 2.30. While the students' learning achievement with a low need for achievement, it gained the lowest score is 4 , the highest score is 14 , the average is 8.35 , and the standard deviation is 2.92 .

\subsection{Analysis requirement tests}

Next, the analysis requirements test is first performed before testing the hypothesis. The tests are data normality test and the homogeneity test. Data normality test results are shown in Table 3. Based on Table 3 it can be concluded that the research data are normally distributed. After the assumption of data normality has been fulfilled, then continued with the test of homogeneity requirements which shown in Table 4. Based on Table 4, the value of Fcount is 1.78 which is lower than Ft5\% (2.67) at the significance level $\alpha=5 \%$. Therefore it is concluded that the data between groups is homogeneous. 
Table 3. Result of Kolmogorov-Smirnov test

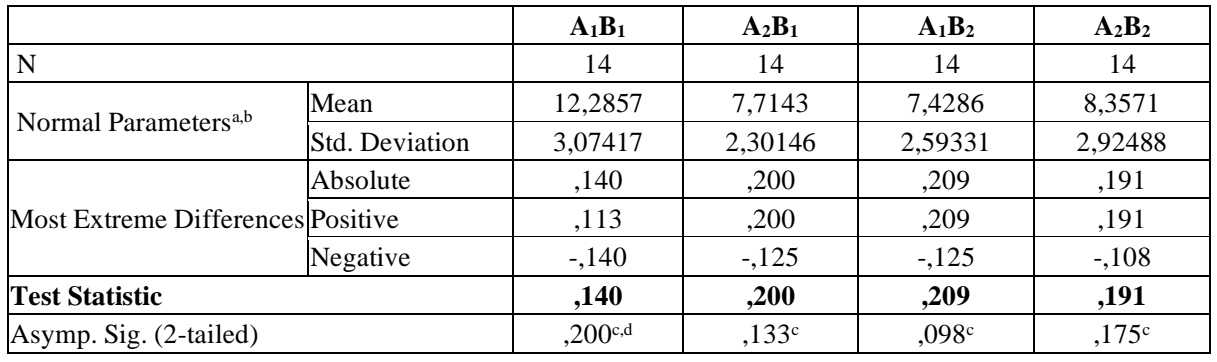

Table 4. Result of homogeneity test

\begin{tabular}{|l|l|c|c|c|c|}
\hline \multicolumn{2}{|c|}{} & X1 & X2 & X3 & X4 \\
\hline \multirow{2}{*}{$N$} & Valid & 14 & 14 & 14 & 14 \\
\cline { 2 - 5 } & Missing & 0 & 0 & 0 & 0 \\
\hline Mean & 12,2857 & 7,7143 & 7,4286 & 8,3571 \\
\hline Median & 12,5000 & 7,0000 & 7,0000 & 8,0000 \\
\hline Mode & 11,00 & 6,00 & $5,00^{\mathrm{a}}$ & 8,00 \\
\hline Std. Deviation & 3,07417 & 2,30146 & 2,59331 & 2,92488 \\
\hline Variance & 9,451 & 5,297 & 6,725 & 8,555 \\
\hline Range & 11,00 & 7,00 & 9,00 & 10,00 \\
\hline Minimum & 5,00 & 5,00 & 4,00 & 4,00 \\
\hline Maximum & 16,00 & 12,00 & 13,00 & 14,00 \\
\hline Sum & 172,00 & 108,00 & 104,00 & 117,00 \\
\hline
\end{tabular}

\subsection{Hypothesis test}

Hypothesis testing can be done because it has met the test analysis requirements. Hypothesis testing used multiple variance analysis techniques (Multi-way ANOVA) and continued with the Tukey Test. After testing it shows that the three null hypotheses (Ho) successfully rejected. A summary of the Multi-way ANOVA test result is shown in Table 5.

Table 5. Result of multi-way ANOVA test

\begin{tabular}{|l|c|c|c|c|c|c|}
\hline \multicolumn{1}{|c|}{ Variant resources } & $\mathbf{d k}$ & $\mathbf{J K}$ & $\mathbf{R J K}$ & $\mathbf{F}_{\text {count }}$ & $\mathbf{F}_{\text {table(5\%) }}$ & $\mathbf{F}_{\text {table(1\%) }}$ \\
\hline Learning achievement (A) & 1 & 46.4464 & 46.4464 & 6.1872 & 4.03 & 7.17 \\
\hline Motivation (B) & 1 & 2.1607 & 62.1607 & 8.2805 & 4.03 & 7.17 \\
\hline Interaction (AB) & 1 & 105.875 & 105.875 & 14.1038 & 4.03 & 7.17 \\
\hline Data error & 52 & 390.3571 & 7.5068 & - & - & - \\
\hline Total & 55 & 604.8392 & - & - & - & - \\
\hline
\end{tabular}

From Table 5 it can be concluded that there are significant difference on students' learning achievement between Google SketchUp and Power Slide application. Then, in the building interior design subject, the learning achievement of students with a high need for motivation has a significant difference than the low need for achieve- 
ment. In addition, there is an interaction between Google SketchUp application and students' need for achievement. Based on the result in Table 5, the hypothesis testing is continued with the Tukey Test. Table 6 shows the results of the Tukey Test.

Based on Table 6 it can be seen that the Google SketchUp application provides a higher learning achievement in building interior design compared to the use of PowerPoint Slides (Qcount $=4.97>$ Qtable $=2.85$ ). There are several previous studies related to this finding. The use of Google SketchUp significantly influences the mental rotation skills of elementary school students in Istanbul (GSD Education Foundation Bahcelievler Primary School in Istanbul) [29]. Students who use Google SketchUp are able to draw graphical shapes exactly as for example, whereas for students who use isometric paper, the graphic images are different from the example. Sumen also outlined his findings that Google SketchUp effectively developed students' mental rotation skills [30]. Then, the 3D SketchUp visuals was more effective than PowerPoint visual in the subject of various wood construction works at State VHS 56 Jakarta [31]. Furthermore, the use of SketchUp software can help students visualize their creativity in interior design courses at the Indonesian Computer University [24]. From several previous related studies, it can be seen that the use of the Google SketchUp application can make learning design effective in primary education, VHS, and higher education.

Table 6. Result of Tukey test

\begin{tabular}{|c|c|c|c|c|}
\hline Factor & Mean & $\mathbf{Q}_{\text {count }}$ & $\mathbf{Q}_{\text {table }}$ & Remarks \\
\hline Google SketchUp application & 9.85 & \multirow{2}{*}{4.97} & \multirow{2}{*}{2.85} & \multirow{2}{*}{ Significant } \\
\hline PowerPoint Slide aplication & 8.03 & & & \\
\hline High need for achievement & 10.00 & \multirow{2}{*}{5.75} & \multirow{2}{*}{2.85} & \multirow{2}{*}{ Significant } \\
\hline Low need for achievement motivation & 7.89 & & & \\
\hline $\begin{array}{l}\text { Google SketchUp application with high need for achieve- } \\
\text { ment }\end{array}$ & 12.28 & \multirow{2}{*}{8.84} & \multirow{2}{*}{2.91} & \multirow{2}{*}{ Significant } \\
\hline $\begin{array}{l}\text { Slide PowerPoint application with high need for achieve- } \\
\text { ment }\end{array}$ & 7.71 & & & \\
\hline Google SketchUp application with low need for achievement & 7.43 & \multirow{2}{*}{1.18} & \multirow{2}{*}{2.91} & \multirow{2}{*}{ No Significant } \\
\hline Slide PowerPoint application with low need for achievement & 8.36 & & & \\
\hline
\end{tabular}

Furthermore, students with a high need for achievement gain a higher learning achievement rather than the low one $($ Qcount $=5.75>$ Qtable $=2.85)$. Several studies related to this finding describes that students who have a good need for achievement motivation have an efforts to achieve high levels of success and are happy with a competitive environment [32], [33]. In addition, the need for achievement influences academic flow for high school X students in Surabaya [34]. Students who have a good need for achievement can concentrate fully when studying.

For students classified with a high need for achievement, there is a significant difference in learning achievement between the Google SketchUp application and PowerPoint Slides $($ Qcount $=8.84>$ Qtable $=2.91)$. This gives a clue that vocational students with a high need for achievement should be pursued using the Google SketchUp application in building interior design learning. However, for students classified as a low need for achievement, there is no significant difference in learning achievement 
between Google SketchUp and PowerPoint slides application (Qcount $=1.18<$ Qtable $=2.91$ ). This shows that students with a low need for achievement do not have problems of decreasing learning achievement in building interior design, although taught by using the Google SketchUp application or with PowerPoint Slides.

Based on Table 5, it can be concluded that there is an interaction between the use of the Google SketchUp and PowerPoint Slide with need for achievement that affects the students' learning achievement. Figure 4 shows the profile plots of interaction picture.

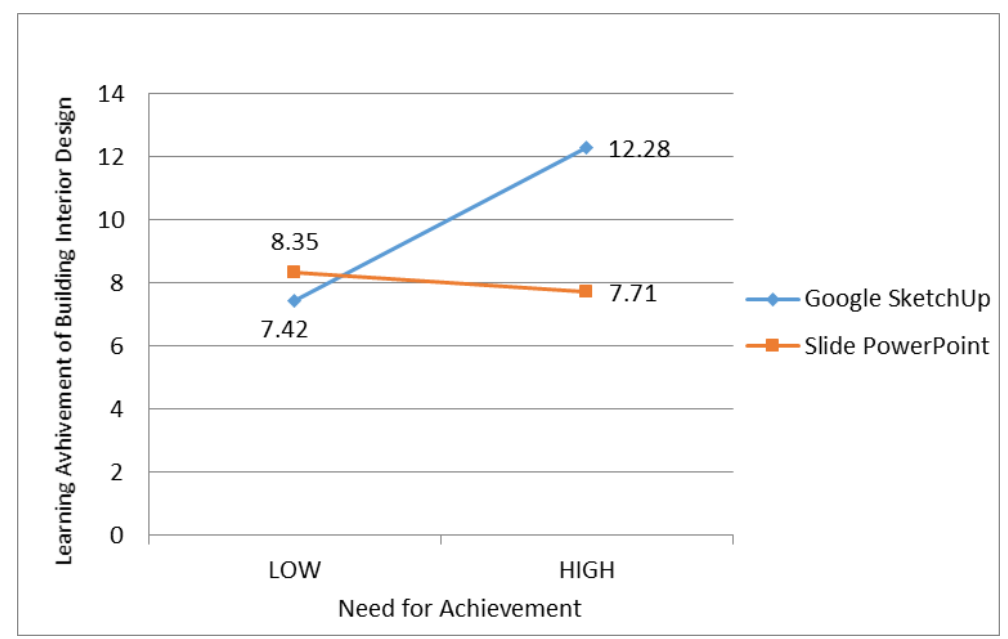

Fig. 4. Interaction Google SketchUp application with a students' need for achievement

This finding is useful for the development of vocational education management as an effort to improve the learning process of VHS students in the context of implementing VHS revitalization. However, it is also possible that these findings can applied in more learning subjects of VHS education. This finding can also be used as input for the Principals and decision makers in the Ministry of Education and Culture related to the vocational learning process.

Moreover, the use of technology to assist learning should be suitable with students' behavior [35], [36]. Therefore, teacher has an important role to analyze and decide a technology that suitable for learning process [37], [38]. Also, the teacher should be follow the development of technology to utilize it effectively [39], [40]. This is can be a reference to future research related to the technology-based learning.

According to the findings of this study, for vocational students has high need for achievement, the use of the Google SketchUp application is more effective than PowerPoint slides in interior design learning. This finding supports with the related previous research [29]-[32]. Vocational students with high need for achievement have higher learning achievements in interior design than students with low need for achievement. This finding supports with the related previous research [33]. Based on the research findings, the following is recommended for interior design teachers and subsequent researchers: 1) The Google SketchUp application can be used to model 3D 
objects in interior design; 2) Before using the Google SketchUp application in learning, teachers should first measure student's motivation; 3) For further research, researchers can examine the effect of using the Google SketchUp application and motivation on student achievement in different levels.

\section{Conclusion}

Based on the result in this study, it shows that the Google SketchUp application is more effective compared to the use of PowerPoint slides in the building interior design learning. Then, the students with a high need for achievement gained a higher learning achievement than the student with a low need for achievement. In addition, there is an interaction between the Google SketchUp application and the need for achievement of students in building interior design learning. For students classified as a high need for achievement, the Google SketchUp application is significantly more effective than using PowerPoint Slides. However, for students with a low need for achievement, the Google SketchUp application does not differ significantly compared to the use of PowerPoint Slides.

Furthermore, there are several recommendation related to the research findings. Before using the any application in learning, teachers should first measure and analyze student's motivation in order to decide the suitable technology to used. Also, researchers can examine the effect of using the Google SketchUp application and motivation on student achievement in different levels.

\section{Acknowledgement}

Thank you to the Head of the Medan State University (UNIMED) who provided funding for this research in 2019. Thank you also to the Chairperson of the UNIMED Community Service Research Institute, the head of UNIMED Faculty of Engineering, and the Principal of the State VHS 1 Stabat that give permission, so that research can be carried out properly in accordance with the design. Acknowledgments are also conveyed to all those who have provided support or participation in the research implementation.

\section{$7 \quad$ References}

[1] K. Schwab, "The Fourth Industrial Revolution," Sociology, 2016. [Online]. Available: https://www.semanticscholar.org/paper/The-Fourth-Industrial-RevolutionSchwab/31daf7c02547fe4e8faf6c96a2a54278c2d5ba8a. [Accessed: 16-Jul-2019].

[2] E. R. Allen, "Analysis of Trends and Challenges in the Indonesian Labor Market," Asian Dev. Bank, 2016.

[3] A. F. Hendarman and J. H. Tjakraatmadja, "Relationship among Soft Skills, Hard Skills, and Innovativeness of Knowledge Workers in the Knowledge Economy Era," Procedia Soc. Behav. Sci., vol. 52, pp. 35-44, 2012. https://doi.org/10.1016/j.sbspro.2012.09.439 
[4] A. Kayahan Karakul, "Educating labour force for a green economy and renewable energy jobs in Turkey: A quantitave approach," Renew. Sustain. Energy Rev., vol. 63, pp. 568578, 2016. https://doi.org/10.1016/j.rser.2016.05.072

[5] M. M. Amin, "Strategi Implementasi Revitalisasi SMK (10 Langkah Revitalisasi SMK)." Direktorat Pembinaan Sekolah Menengah Kejuruan, Jakarta, 2017.

[6] V. Oyedele, J. Rwambiwa, and A. Mamvuto, "Using Educational Media and Technology in Teaching and Learning Processes: A Case of Trainee Teachers at Africa University," Acad. Res. Int., vol. 4, no. 1, pp. 292-300, 2013.

[7] H. Elmunsyah, W. N. Hidayat, and K. Asfani, "Interactive learning media innovation: utilization of augmented reality and pop-up book to improve user's learning autonomy," J. Phys. Conf. Ser., vol. 1193, no. 1, 2019. https://doi.org/10.1088/1742-6596/1193/1/012031

[8] Y. T. Sung, K. E. Chang, and T. C. Liu, "The effects of integrating mobile devices with teaching and learning on students' learning performance: A meta-analysis and research synthesis," Comput. Educ., vol. 94, pp. 252-275, 2016. https://doi.org/10.1016/j.compedu. $\underline{2015.11 .008}$

[9] D. Adrianto, V. Yesmaya, and A. Chandra, "Increasing learning frequency through education based game,” J. Comput. Sci., vol. 11, no. 3, pp. 567-572, 2015. https://doi.org/10.38 44/jessp.2015.567.572

[10] E. S. Duh and N. Koceska, "Game-based learning: educational game Azbuka to help young children learn writing Cyrillic letters,” Multimed. Tools Appl., 2016. https://doi.org/ $\underline{10.1007 / \mathrm{s} 11042-016-3829-9}$

[11] Y. Wang, A. Qi, and F. Cui, "Application of the Multimedia Teaching System Based on Real-time Shooting and Production in Martial Art Course,” Int. J. Emerg. Technol. Learn., vol. 11, no. 3, 2016. https://doi.org/10.3991/ijet.v11i03.5347

[12] M. Kalogiannakis and S. Papadakis, "Combining mobile technologies in environmental education: a Greek case study,” Int. J. Mob. Learn. Organ., vol. 11, no. 2, pp. 108-130, 2017.

[13] D. Spikol and J. Eliasson, "Lessons from designing geometry learning activities that combine mobile and 3D tools," in 2010 6th IEEE International Conference on Wireless, Mobile, and Ubiquitous Technologies in Education, 2010, pp. 137-141. https://doi.org/10.110 9/wmute.2010.44

[14] P. Laisney and P. Brandt-Pomares, "Role of graphics tools in the learning design process," Int. J. Technol. Des. Educ., vol. 25, no. 1, pp. 109-119, 2015. https://doi.org/10.1007/s107 98-014-9267-y

[15] S. E. Smaldino, D. L. Lowther, and C. Mims, Instructional Technology and Media for Learning. New Jersey: Pearson Education, Inc, 2008.

[16] J. E. Ormrod, Educational Psychology Developing Learner. New Jersey: Prentice Hall, Inc., 2008.

[17] S. P. Robbins and T. Judge, Organizational Behavior. Prentice Hall, 2007.

[18] S. M. Carraher, J. K. Buchanan, and G. Puia, "Entrepreneurial need for achievement in China, Latvia, and the USA,” Balt. J. Manag., vol. 5, no. 3, pp. 378-396, 2010. https://doi. org/10.1108/17465261011079767

[19] G. B. Moneta, "Need for achievement, burnout, and intention to leave: Testing an occupational model in educational settings," Pers. Individ. Dif., vol. 50, no. 2, pp. 274-278, 2011. https://doi.org/10.1016/j.paid.2010.10.002

[20] S. Azwar, Penyusunan Skala Psikologi. Yogyakarta: Pustaka Pelajar, 2009.

[21] P. J. Kpolovie, A. I. Joe, and T. Okoto, “Academic achievement prediction: Role of interest in learning and attitude towards school," Int. J. Humanit. Soc. Sci. Educ., vol. 1, no. 11, pp. 73-100, 2014. 
[22] T. Khuon, "Do You Have High Need for Achievement?" Evolutionary Psychology, 2014. [Online]. Available: http://agilelifestyle.net/need-for-achievement. [Accessed: 16-Nov2019].

[23] W. R. Borg and M. D. Gall, Educational research an introduction. New York: Longman Publishing, 2003.

[24] M. T. Puth, M. Neuhäuser, and G. D. Ruxton, "Effective use of Pearson's productmoment correlation coefficient," Anim. Behav., vol. 93, pp. 183-189, 2014. https://doi. org/10.1016/j.anbehav.2014.05.003

[25] Y. Yang and S. B. Green, "Coefficient alpha: A reliability coefficient for the 21 st century?” J. Psychoeduc. Assess., vol. 29, no. 4, pp. 377-392, 2011.

[26] N. M. Razali and Y. B. Wah, "Power comparisons of shapiro-wilk, kolmogorov-smirnov, lilliefors and anderson-darling tests," J. Stat. Model. Anal., vol. 2, no. 1, pp. 21-33, 2011.

[27] J. L. Gastwirth, Y. R. Gel, and W. Miao, "The impact of Levene's test of equality of variances on statistical theory and practice," Stat. Sci., vol. 24, no. 3, pp. 343-360, 2009. https ://doi.org/10.1214/09-sts301

[28] H. Abdi and L. J. Williams, "Newman-Keuls test and Tukey test," in Encyclopedia of Research Design, N. Salkind, Ed. Thousands Oaks, CA: SAGE Publications, 2010, pp. 1-11.

[29] M. F. Erkoc, Z. Gecu, and C. Erkoc, "The effects of using Google SketchUp on the mental rotation skills of eighth grade students," Educ. Sci. Theory Pract., vol. 13, no. 2, pp. 12851294, 2013.

[30] Ö. Ö. Sümen, "Enhancing Mental Rotation Skills through Google SketchUp," Univers. J. Educ. Res., vol. 6, no. 11, pp. 2586-2596, 2018. https://doi.org/10.13189/ujer.2018.06112 $\underline{4}$

[31] R. Ramadhan, A. Maulana, and D. Rochadi, "Pengaruh Media Pembelajaran Visual Tiga Dimensi (Sketch Up) Terhadap Hasil Belajar Siswa pada Materi Pelajaran Macam-Macam Pekerjaan Konstruksi Kayu,” J. Pendidik. Tek. Sipil, vol. 7, no. 1, 2018. https://doi.org/10. 21009/pensil.7.1.4

[32] R. Zeffane, "Need for achievement, personality and entrepreneurial potential: A study of young adults in the United Arab Emirates," J. Enterprising Cult., vol. 21, no. 01, pp. 75105, 2013. https://doi.org/10.1142/s0218495813500040

[33] S. Chen, X. Su, and S. Wu, "Need for achievement, education, and entrepreneurial risktaking behavior," Soc. Behav. Personal. an Int. J., vol. 40, no. 8, pp. 1311-1318, 2012. https://doi.org/10.2224/sbp.2012.40.8.1311

[34] E. Prihandrijani, "Pengaruh Motivasi Berprestasi dan Dukungan Sosial Terhadap Flow Akademik Pada Siswa SMA X di Surabaya," Universitas Airlangga, 2016.

[35] N. Vidakis, A. K. Barianos, A. M. Trampas, S. Papadakis, M. Kalogiannakis, and K. Vassilakis, "Generating Education in-Game Data: The Case of an Ancient Theatre Serious Game," in Proceedings of the 11th International Conference on Computer Supported Education (CSEDU 2019), 2019, pp. 36-43. https://doi.org/10.5220/0007810800360043

[36] P. Celik, F. Onder, and I. Silay, "The effects of problem-based learning on the students' success in physics course,” Procedia-Social Behav. Sci., vol. 28, pp. 656-660, 2011. https ://doi.org/10.1016/j.sbspro.2011.11.124

[37] S. Papadakis and M. Kalogiannakis, "Evaluating a course for teaching introductory programming with Scratch to pre-service kindergarten teachers," Int. J. Technol. Enhanc. Learn., vol. 11, no. 3, pp. 231-246, 2019. https://doi.org/10.1504/ijtel.2019.10020447

[38] S. Papadakis, "Evaluating pre-service teachers' acceptance of mobile devices with regards to their age and gender: a case study in Greece," Int. J. Mob. Learn. Organ., vol. 12, no. 4, pp. 336-352, 2018. https://doi.org/10.1504/ijmlo.2018.10013372 
[39] M. Kalogiannakis and S. Papadakis, "Evaluating pre-service kindergarten teachers' intention to adopt and use tablets into teaching practice for natural sciences," Int. J. Mob. Learn. Organ., vol. 13, no. 1, pp. 113-127, 2019. https://doi.org/10.1504/ijmlo.2019.10016617

[40] H. Holden and R. Rada, "Understanding the influence of perceived usability and technology self-efficacy on teachers' technology acceptance," J. Res. Technol. Educ., vol. 43, no. 4, pp. 343-367, 2011. https://doi.org/10.1080/15391523.2011.10782576

\section{Authors}

Nathanael Sitanggang is a lecturer in the Building Engineering Education Study Program, Faculty of Engineering, State University of Medan, Indonesia. He joined the professional organization of the Ikatan Sarjana Manajemen Pendidikan Indonesia (ISMAPI), Perkumpulan Ahli Pendidikan Teknologi dan Kejuruan Indonesia (PAPTEKINDO), Asosiasi Dosen \& Guru Vokasi Indonesia (ADGVI), and since 2019 joined the ASEAN Federation of Engineering Organizations (AFEO Governing Organization) Board). His current research topic is Leadership Effectiveness that Supports the Success of the VHS Revitalization Program.

Putri Lynna Adelinna Luthan is a lecturer in the Civil Engineering Study Program, Faculty of Engineering, State University of Medan, Indonesia. Since 2019 she have joined the professional organization of the ASEAN Federation of Engineering Organizations (AFEO Governing Board) which engages in Engineering. The research topic is Enhancing Engineer Ability in the field of Civil Engineering and its application based on digital technology.

Felix Andika Dwiyanto is currently a master student in the graduate school of State University of Malang, Indonesia. His major study is related to engineering and vocational education especially in field of informatics. He joins a professional organization namely ASCEE since 2017 as an associate editor of BUSINTA Journal. Now his topics research is related to training program to improve a quality of vocational education teachers and the application of technology-based education.

Article submitted 2019-11-21. Resubmitted 2020-03-18. Final acceptance 2020-03-18. Final version published as submitted by the authors. 